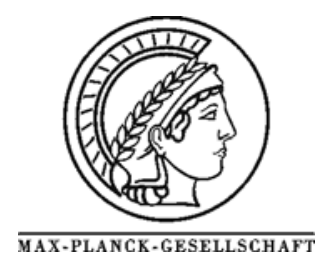

\title{
Impact of preparation method on physico-chemical and catalytic properties of $\mathrm{VO}_{\mathrm{x}} / \mathrm{Y}-\mathrm{Al}_{2} \mathrm{O}_{3}$ materials
}

\author{
O. Schwarz ${ }^{1)}$, D. Habel ${ }^{2)}$, O. Ovsitser ${ }^{3)}$, E.V. Kondratenko ${ }^{3)}$, C. Hess ${ }^{4)}$, R. Schomäcker ${ }^{1), *}$, H. Schubert ${ }^{2)}$
}

\author{
${ }^{1)}$ Department of Chemistry, Technical University of Berlin, Straße des 17. Juni 124-128, D-10623 Berlin, Germany \\ ${ }^{2)}$ Institute for Material Science and Technologies, Technical University of Berlin, \\ Englische Straße 20, D-10587 Berlin, Germany \\ ${ }^{3)}$ Leibniz-Institut für Katalyse e.V. an der Universität Rostock, Außenstelle Berlin, \\ Richard-Willstätter-Str. 12, D-12489 Berlin, Germany \\ ${ }^{4)}$ Department of Inorganic Chemistry, Fritz-Haber-Institute of the Max Planck Society, \\ Faradayweg 4-6, D-14195 Berlin, Germany
}

* Corresponding author: e-mail schomaecker@tu-berlin.de, Tel: +49 (0)30 314249 73,Fax: +49 (0)30 31421595

Received 4 February 2008; revised 24 April 2008; accepted 21 July 2008. Available online 29 July 2008

\begin{abstract}
Two preparation methods (wet saturation impregnation with vanadyl acetylacetonate and ball-milling of $\gamma-\mathrm{Al}_{2} \mathrm{O}_{3}$ with crystalline $\mathrm{V}_{2} \mathrm{O}_{5}$ ) were applied to produce two sets of $\mathrm{VO}_{\mathrm{x}} / \gamma-\mathrm{Al}_{2} \mathrm{O}_{3}$ catalysts with increasing vanadium loadings. Materials from both sets were characterized by XRD, SEM, Raman, TPR and UV/Vis-DRS to elucidate the influence of the preparation method on the morphology of $\mathrm{VO}_{\mathrm{x}}$ species and on their behavior in the oxidative dehydrogenation of propane (ODP). Edge energies from UV/Vis-DRS experiments were correlated with activity and selectivity data; the lower the edge energy, the lower catalytic activity and the higher propene selectivity. Both preparation methods result in materials with comparable physico-chemical and catalytic properties although very different precursors were used. Especially the calcination step during catalyst preparation seems to transform the different precursor molecules to dispersed $\mathrm{VO}_{\mathrm{x}}$ species by an equilibration process on the support material surface.
\end{abstract}

Keywords: $\mathrm{VO}_{x}, \mathrm{~V}_{2} \mathrm{O}_{5}, \mathrm{Al}_{2} \mathrm{O}_{3}$, Preparation method, Ball milling, Propane, $\mathrm{ODH}$, Oxidative dehydrogenation, Edge energy

\section{Introduction}

Lower olefins are important base chemicals for many industrial applications. They are conventionally produced from non-oxidative, high-temperature cracking processes. Particularly for the production of propene, the oxidative dehydrogenation of propane (ODP) has long been suggested as an alternative reaction pathway [1,2]. This process is energetically favored due to a lower energy input and offers further advantages in terms of catalyst lifetime since coking is not as severe. Moreover, the ODP does not suffer from thermodynamic limitations in contrast to the non-oxidative industrially applied processes. Although the oxidative dehydrogenation has been extensively investigated, propene yields over $30 \%$ under anticipated operating conditions have not been achieved yet [3].

In addition to the economic interest in this reaction, the ODP has long been subject to academic research, too [3-7]. Numerous catalytic systems have been evaluated for this reaction and the relevant results have been recently reviewed $[3,8,9]$. Especially vanadium containing catalysts were targeted by past studies, because they belong to the 
most promising catalytic systems [10-20]. The major challenge is to minimize the formation of carbon oxides $\left(\mathrm{CO}_{\mathrm{x}}\right)$ via consecutive total oxidation of propene that is favored at high degrees of propane conversion due to a higher reactivity of propene as compared to propane. Several physicochemical properties such as reducibility of $\mathrm{VO}_{\mathrm{x}}$ species, their structure and electronic properties can influence both, selective and non-selective reaction pathways in different directions through a variation of vanadium loading or support material $[6,12,13,14,15,21-26]$. It seems that highly dispersed $\mathrm{VO}_{\mathrm{x}}$ species (i.e. predominantly monovanadates) over non-acidic supports are more selective than polymerized ones [12,14,25,27-29]. In contrast, polymerized $\mathrm{VO}_{\mathrm{x}}$ species (no bulk like crystalline $\mathrm{V}_{2} \mathrm{O}_{5}$ ) are considered to be more active than highly dispersed ones.

It should be stressed that the relationships described above have been established for catalytic materials prepared by impregnation techniques of various supports. To the best of our knowledge, no investigations have been performed on materials prepared by ball-milling of support and active component for the ODP. It is important to understand whether the nature of $\mathrm{VO}_{\mathrm{x}}$ species and their catalytic performance are influenced by the type of vanadium precursor and the preparation method applied. To this end, two sets of $\mathrm{VO}_{\mathrm{x}} / \gamma-\mathrm{Al}_{2} \mathrm{O}_{3}$ catalysts with increasing vanadium loadings were prepared by wet saturation impregnation of $\gamma-\mathrm{Al}_{2} \mathrm{O}_{3}$ and by ball-milling of crystalline $\mathrm{V}_{2} \mathrm{O}_{5}$ and the same $\gamma-\mathrm{Al}_{2} \mathrm{O}_{3}$. In order to compare the influence of the preparation method and the resulting nature of $\mathrm{VO}_{\mathrm{x}}$ species on the catalytic performance, the vanadium loading was chosen similar for both preparation methods. The samples were thoroughly characterized to get insights into the nature of $\mathrm{VO}_{\mathrm{x}}$ species, their distribution and redox properties. The degree of polymerization of $\mathrm{VO}_{\mathrm{x}}$ surface species was investigated and correlated with catalytic activity and selectivity.

\section{Experimental}

\subsection{Catalyst preparation}

For the first preparation method, vanadyl acetylacetonate (Fluka, item no. 94735) was used to precipitate vanadium onto the alumina surface through a wet saturation impregnation technique. This particular technique was chosen because it allows for the stabilization of highly dispersed $\mathrm{VO}_{\mathrm{x}}$ species on the catalyst surface [30]. The $\gamma$ $\mathrm{Al}_{2} \mathrm{O}_{3}$ pellets (Alfa Aesar, item no. 43857, diameter $0.3 \mathrm{~mm}$, length $5 \mathrm{~mm}$ ) were crushed and sieved to obtain particles with a size distribution between 100 and $300 \mu \mathrm{m}$. For the first impregnation, $21 \mathrm{~g}$ of the support material were added slowly to a saturated mixture of vanadyl acetylacetonate in toluene (Roth, item no. 95583) with a concentration of $66 \mathrm{mmol} \mathrm{l}^{-1}$. The mixture was then heated and treated under reflux for $30 \mathrm{~min}$. Afterwards, the impregnated particles were washed with fresh toluene, dried at
$80{ }^{\circ} \mathrm{C}$ in a drying cabinet and finally calcined in air at $500{ }^{\circ} \mathrm{C}$ for $5 \mathrm{~h}$. After the first impregnation cycle was completed, $3 \mathrm{~g}$ of the obtained material were kept for characterization and catalytic testing. The remaining grains produced from the first impregnation were treated again as described above. After each step, $3 \mathrm{~g}$ were kept for further investigations. This procedure was repeated seven times.

For the second preparation method, crystalline $\mathrm{V}_{2} \mathrm{O}_{5}$ in the Shcherbinaite modification (GfE Environmental Technology, item no. 2008620) and the same $\gamma-\mathrm{Al}_{2} \mathrm{O}_{3}$ pellets as described above were taken for preparing the catalytic materials. Both oxides were used as fine powders. They were homogenized by ball-milling (Retsch, PM4) in dried cyclohexane for $60 \mathrm{~min}$ at a milling-speed of $110 \mathrm{rpm}$. The volume of one grinding beaker (inner surface coated with silica carbide) was $350 \mathrm{ml}$. The balls (also made from silica carbide) were about $10 \mathrm{~mm}$ in diameter. After milling the samples were dried at $100{ }^{\circ} \mathrm{C}$ and subsequently calcined in air at $500{ }^{\circ} \mathrm{C}$ for $4 \mathrm{~h}$.

The names given to the catalytic samples were organized as follows: "V-X-Y", where $\mathrm{X}$ resembles the preparation method ( $\mathrm{I}=$ wet saturation impregnation or II = ballmilling of the individual oxides) and $\mathrm{Y}$ resembles the apparent surface density of the $\mathrm{VO}_{\mathrm{x}}$ species in $\mathrm{V}$ atoms per $\mathrm{nm}^{2}$. For example, $\mathrm{V}-\mathrm{I}-1.5$ refers to a $\mathrm{VO}_{\mathrm{x}} / \gamma-\mathrm{Al}_{2} \mathrm{O}_{3}$ catalyst prepared by wet saturation impregnation, possessing an apparent $\mathrm{VO}_{\mathrm{x}}$ surface density of $1.5 \mathrm{~V} \mathrm{~nm}^{-2}$.

\subsection{Catalyst characterization}

Inductively Coupled Plasma-Optical Emission Spectroscopy (ICP-OES) was used to determine the vanadium concentrations of each catalyst after calcination. Before the analysis, the samples were dried at $350{ }^{\circ} \mathrm{C}$ for $2 \mathrm{~h}$ in air. Afterwards, the solid catalytic materials were fully dissolved by microwave-pressure pulping and kindly analyzed by Atotech Deutschland GmbH.

The BET surface areas of the $\gamma-\mathrm{Al}_{2} \mathrm{O}_{3}$ support and the differently prepared catalytic materials were determined using nitrogen adsorption at $77 \mathrm{~K}$ with a Micromeritics Gemini III 2375 Surface Area Analyzer. Before measurements, the samples were heated for $90 \mathrm{~min}$ at $250{ }^{\circ} \mathrm{C}$ under vacuum using a Vacprep 061 degasser.

The crystalline phase composition of the $\mathrm{VO}_{\mathrm{x}} / \gamma$ $\mathrm{Al}_{2} \mathrm{O}_{3}$ materials was determined by $\mathrm{X}$-ray powder diffraction (XRD). A 20-diffractometer (Bruker AXS, D5005, variable divergence slits, position sensitive detector) with $\mathrm{Cu} \mathrm{K \alpha}$ radiation $(\lambda=0.1542 \mathrm{~nm})$ was used for measurements in an angle range $2 \theta$ from $10^{\circ}$ to $90^{\circ}$. The phase analysis was carried out using the Diffrac-Plus/ Search program.

Scanning electron microscopy (SEM) was applied for structural characterization of the catalysts. Specimens were glued onto alumina stubs, then gold-coated and examined using a Philips XL 20 scanning electron micro- 
scope at an accelerating voltage of $5 \mathrm{kV}$ in order to avoid charging.

In-situ Raman spectroscopy was performed using a fiber probe which was inserted into a Raman cell. The samples were placed in a stainless steel sample holder with a $0.6 \mathrm{~mm}$ deep rectangular well covering an area of $(12 \times 8) \mathrm{mm}^{2}$. Before running the analysis, the samples were dehydrated for $60 \mathrm{~min}$ by treatment in a $20 / 80 \mathrm{O}_{2} / \mathrm{N}_{2}$ flow $\left(50 \mathrm{ml}_{\mathrm{n}} \mathrm{min}^{-1}\right)$ at $350{ }^{\circ} \mathrm{C}$ and subsequently cooled to room temperature. Raman spectra were recorded using $514 \mathrm{~nm}$ laser excitation $(5 \mathrm{~mW})$ at $5 \mathrm{~cm}^{-1}$ spectral resolution (Kaiser Optical). Sampling times were typically $30 \mathrm{~min}$.

Temperature programmed reduction (TPR) experiments were performed to get insights into the reducibility of the $\mathrm{VO}_{\mathrm{x}}$ species. Prior to TPR measurements, the samples were heated under a 50/50 $\mathrm{O}_{2} / \mathrm{He}$ flow $\left(50 \mathrm{ml}_{\mathrm{n}} \mathrm{min}^{-1}\right)$ up to $500^{\circ} \mathrm{C}$ and kept at this temperature for $30 \mathrm{~min}$. The pre-treatment is necessary in order to fully oxidize the $\mathrm{VO}_{\mathrm{x}}$ species before $\mathrm{H}_{2}$-reduction. After oxidation, the samples were cooled to $50{ }^{\circ} \mathrm{C}$ and then heated with $10^{\circ} \mathrm{C} \mathrm{min}^{-1}$ up to $860{ }^{\circ} \mathrm{C}$ in a gas mixture of $5 / 95 \mathrm{H}_{2} / \mathrm{Ar}$ with a total gas flow of $25 \mathrm{ml}_{\mathrm{n}} \mathrm{min}^{-1}$. Hydrogen consumption was monitored by a mass spectrometer (InProcess Instruments GAM 200).

In order to analyze the degree of polymerization of $\mathrm{VO}_{\mathrm{x}}$ species in the differently prepared and loaded $\mathrm{VO}_{\mathrm{x}} / \gamma$ $\mathrm{Al}_{2} \mathrm{O}_{3}$ materials, in-situ UV/Vis diffuse reflectance spectroscopy (UV/Vis-DRS) was applied. Experiments were performed using an Avaspec fiber optical spectrometer (Avantes) equipped with a DH-2000 deuterium-halogen light source and a CCD array detector. The pure $\gamma-\mathrm{Al}_{2} \mathrm{O}_{3}$ support was used as a white reference material and the shut aperture as a black reference. A high-temperature reflection probe, consisting of six radiating and one reading optical fibers, was located inside the furnace at a $90^{\circ}$ angle to the reactor. The sensor was connected to the spectrometer and the light source by fiber optical cables (length $2 \mathrm{~m}$ ) consisting of a core of pure silica (diameter $0.4 \mathrm{~mm}$ ) coated with polyimide. UV/Vis spectra were recorded at $500{ }^{\circ} \mathrm{C}$ in a $20 / 80 \mathrm{O}_{2} / \mathrm{Ne}\left(40 \mathrm{ml}_{\mathrm{n}} \mathrm{min}^{-1}\right)$ and converted into the Kubelka-Munk function.

\subsection{Catalytic tests}

The oxidative dehydrogenation of propane (ODP) to propene was used as a test reaction for comparing both sets of catalytic materials in a six-channel screening apparatus. Experiments were carried out using fixed bed tubular continuous flow reactors made of quartz glass (inner diameter $6 \mathrm{~mm}$ ) with plug flow hydrodynamics at ambient pressure. For catalytic measurements, both sets of materials were taken as fine powders with a particle diameter $<100 \mu \mathrm{m}$ (the grains from wet saturation impregnation were ground again) to positively avoid mass transport phenomena. For better heat transfer, all catalysts were diluted with $1.5 \mathrm{~g}$ quartz sand resulting in similar bed lengths. The reactors containing the diluted catalyst between two layers of quartz were immersed into a fluidized bed of sand serving as a heat source to provide near isothermal operation conditions. Blind testing of empty reactors, reactors filled with quartz sand and pure $\gamma-\mathrm{Al}_{2} \mathrm{O}_{3}$ did not lead to detectable conversions at $500{ }^{\circ} \mathrm{C}$. The ratio of $\mathrm{C}_{3} \mathrm{H}_{8} / \mathrm{O}_{2} / \mathrm{N}_{2}$ of the inlet flow was $2 / 1 / 4$, using synthetic air as oxygen source. Catalytic tests were carried out at $500^{\circ} \mathrm{C}$. In order to achieve different degrees of $\mathrm{C}_{3} \mathrm{H}_{8}$ conversion, catalyst amounts and total volume flows were varied from 5 to $100 \mathrm{mg}$ and 30 to $200 \mathrm{ml}_{\mathrm{n}} \min ^{-1}$, respectively. Reaction products were analyzed by a gas chromatograph (Satochrom) equipped with a flame ionization detector and a thermal conductivity detector as well as a fused silica capillary column and a molecular sieve column. As reaction products, $\mathrm{C}_{3} \mathrm{H}_{6}, \mathrm{CO}, \mathrm{CO}_{2}$ and $\mathrm{H}_{2} \mathrm{O}$ were detected. The duration of one $\mathrm{GC}$ analysis run was about $15 \mathrm{~min}$ which is longer than the time to achieve steady state conditions after the channel was changed.

Propane conversion $\left(\mathrm{X}_{\mathrm{C} 3 \mathrm{H} 8}\right)$ and propene selectivity $\left(\mathrm{S}_{\mathrm{C} 3 \mathrm{H} 6}\right)$ were calculated from inlet and outlet concentrations, whereas reaction rates $\left[\mathrm{mol}_{\mathrm{C} 3 \mathrm{H} 8} \mathrm{~g}^{-1} \mathrm{~s}^{-1}\right]$ and turn over frequencies $\left[\mathrm{mol}_{\mathrm{C} 3 \mathrm{H} 8} \mathrm{~mol}_{\mathrm{V}}{ }^{-1} \mathrm{~s}^{-1}\right]$ of $\mathrm{C}_{3} \mathrm{H}_{8}$ consumption were determined according to Eqs. 1 and 2:

$$
r=\frac{X_{C 3 H 8} \cdot p_{C 3 H 8} \cdot F}{m_{C a t} \cdot V_{m}}
$$

$$
T O F=\frac{r \cdot m_{C a t}}{n_{V}}
$$

where $\mathrm{p}_{\mathrm{C} 3 \mathrm{H} 8}$ is the partial pressures for propane at the reactor inlet, $\mathrm{F}$ the total volume flow of reactants, $\mathrm{m}_{\mathrm{Cat}}$ the catalyst mass used for experiments, $\mathrm{n}_{\mathrm{V}}$ the vanadium amount in the catalytic samples and $\mathrm{V}_{\mathrm{m}}$ the molar gas volume at $0{ }^{\circ} \mathrm{C}$ and $101325 \mathrm{~Pa}$.

\section{Results and discussion}

\subsection{Catalyst morphology}

The vanadium content and the specific BET surface areas $\left(\mathrm{S}_{\mathrm{BET}}\right)$ of the catalytic materials and the pure $\gamma-\mathrm{Al}_{2} \mathrm{O}_{3}$ support are shown in Tab. 1. For the samples prepared by the wet saturation impregnation method, the vanadium content continuously increases from 1.36 to $6.74 \mathrm{wt} \%$. However, it seems that the amount of vanadium that is precipitated on the alumina support during one impregnation cycle is limited. This might be due to the relatively large acetylacetonate complex that occupies a substantial fraction of the alumina surface limiting the space for other vanadyl acetylacetonate molecules to interact with the sup 
Table 1: Summary of samples used for characterization and catalytic testing

\begin{tabular}{|c|c|c|c|c|c|}
\hline Impregnation & $\begin{array}{c}\gamma- \\
\mathbf{A l}_{2} \mathbf{O}_{3}\end{array}$ & $\begin{array}{l}\text { V-I- } \\
1.5\end{array}$ & $\begin{array}{l}\text { V-I- } \\
4.3\end{array}$ & $\begin{array}{l}\text { V-I- } \\
5.3\end{array}$ & $\begin{array}{l}\text { V-I- } \\
8.8\end{array}$ \\
\hline $\begin{array}{l}\text { V-content } \\
{[\mathrm{wt} \%]}\end{array}$ & - & 1.36 & 3.64 & 4.39 & 6.74 \\
\hline $\mathrm{SA}_{\mathrm{BET}}\left[\mathrm{m}^{2} \mathrm{~g}^{-1}\right]$ & 125 & 109.4 & 103.4 & 101.7 & 97.5 \\
\hline $\begin{array}{l}\text { V-density [V } \\
\mathrm{nm}^{-2} \text { ] }\end{array}$ & - & 1.5 & 4.3 & 5.3 & 8.8 \\
\hline Ball-milling & $\begin{array}{c}\gamma^{-} \\
\mathbf{A l}_{2} \mathbf{O}_{3}\end{array}$ & $\begin{array}{l}\text { V-II- } \\
1.5\end{array}$ & $\begin{array}{l}\text { V-II- } \\
4.8\end{array}$ & $\begin{array}{l}\text { V-II- } \\
5.3\end{array}$ & $\begin{array}{c}\text { V-II- } \\
8.8\end{array}$ \\
\hline $\begin{array}{l}\text { V-content } \\
{[\mathrm{wt} \%]}\end{array}$ & - & 1.32 & 3.96 & 4.39 & 6.46 \\
\hline $\mathrm{SA}_{\mathrm{BET}}\left[\mathrm{m}^{2} \mathrm{~g}^{-1}\right]$ & 125 & 105.4 & 101.1 & 99.4 & 93.4 \\
\hline $\begin{array}{l}\text { V-density [V } \\
\mathrm{nm}^{-2} \text { ] }\end{array}$ & - & 1.5 & 4.8 & 5.3 & 8.8 \\
\hline
\end{tabular}

port surface. Additionally, it was found that the amount of vanadium precipitated per impregnation cycle does not seem to depend on the time the catalyst is treated under reflux. In contrast to the wet impregnation technique, the amount of vanadium in the catalytic materials that are produced from ball-milling can easily be determined by adding exactly the desired quantity of $\mathrm{V}_{2} \mathrm{O}_{5}$ to the alumina support.

For the multiply impregnated catalysts, the surface area slightly decreases with increasing vanadium content to a minimum value of $97.5 \mathrm{~m}^{2} \mathrm{~g}^{-1}$ for V-I-8.8. This is probably due to clogging of pores with $\mathrm{VO}_{\mathrm{x}}$ species decreasing the surface area that is accessible for nitrogen adsorption. A similar effect of vanadium loading on the $\mathrm{S}_{\mathrm{BET}}$ values is also valid for the catalysts prepared by ball-milling of the individual oxides. The lowest $\mathrm{S}_{\mathrm{BET}}$ of $93.4 \mathrm{~m}^{2} \mathrm{~g}^{-1}$ was determined for V-II-8.8.

Taking the vanadium content in each catalytic material and the BET surface areas, the apparent $\mathrm{VO}_{\mathrm{x}}$ surface densities were calculated as $\mathrm{V}$ atoms per $\mathrm{nm}^{2}$ of the catalytic material. As it is shown in Tab. 1, the densities vary between 1.5 and $8.8 \mathrm{~V} \mathrm{~nm}^{-2}$. Values of 2.3 and $7.5 \mathrm{~V} \mathrm{~nm}^{-2}$ are suggested to be characteristic for a monovanadate and polyvanadate monolayer, respectively [16]. Based on the calculated $\mathrm{VO}_{\mathrm{x}}$ surface densities, it is suggested that the obtained materials with $1.5 \mathrm{~V} \mathrm{~nm}^{-2}$ contain predominantly highly dispersed $\mathrm{VO}_{\mathrm{x}}$ species. However, an increase in vanadium loading results generally in a transformation of highly dispersed $\mathrm{VO}_{\mathrm{x}}$ species to polymerized ones. At the same time, the dispersion of $\mathrm{VO}_{\mathrm{x}}$ species decreases simultaneously. Further insights into the distribution of $\mathrm{VO}_{\mathrm{x}}$ species on the catalyst surface were derived from in-situ Raman and UV/Vis-DRS analysis as well as from XRD and temperature programmed reduction tests.

Both sets of catalytic materials were used for X-ray diffraction analysis. All examined samples show broad features of pure $\gamma-\mathrm{Al}_{2} \mathrm{O}_{3}$. None of the catalytic samples

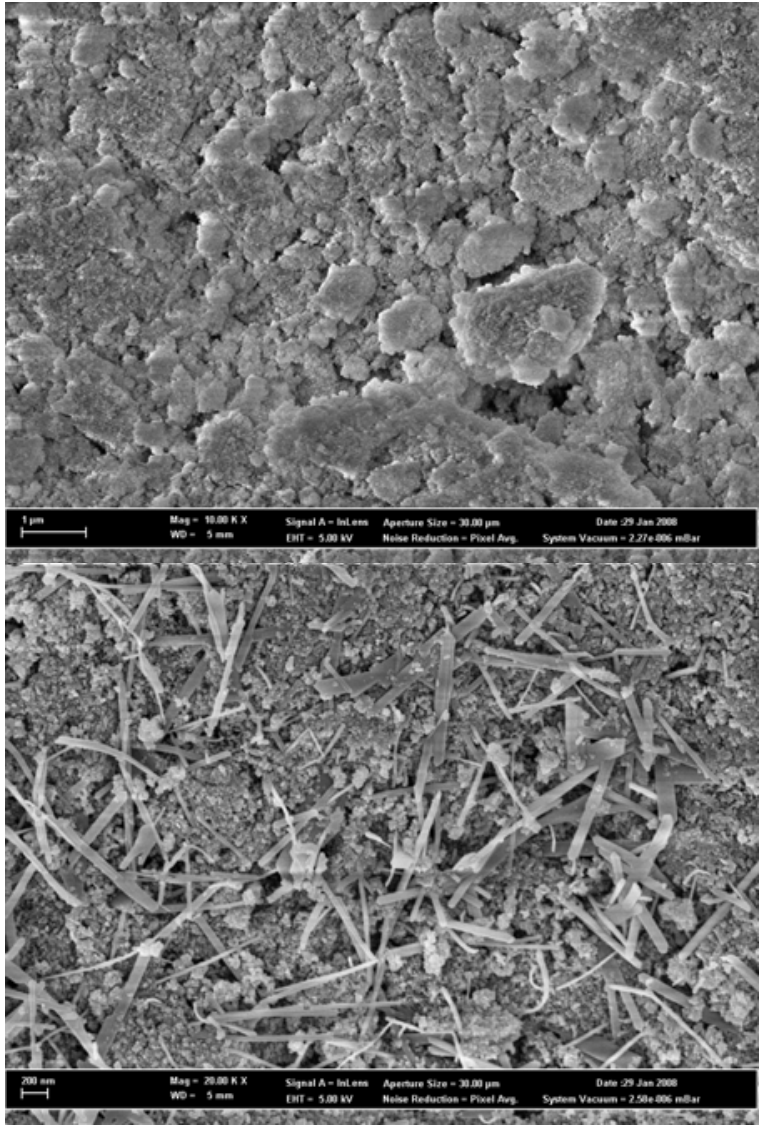

Fig. 1: SEM images of a) V-I-1.5 (resolution $1 \mu \mathrm{m} /$ magnification 10000 ) and b) V-II-8.8 (resolution $200 \mathrm{~nm} /$ magnification 20000 ).

prepared by wet saturation impregnation shows any signs of crystalline $\mathrm{V}_{2} \mathrm{O}_{5}$. This may be explained either as the presence of only small crystalline particles or as surface $\mathrm{VO}_{\mathrm{x}}$ species that cannot be detected by XRD due to the absence of long-range order. On the other hand, V-II-8.8 obtained from ball-milling shows characteristic peaks for $\mathrm{V}_{2} \mathrm{O}_{5}$ at angles of $2 \theta=20^{\circ}(001), 22^{\circ}(101), 26^{\circ}(110)$ and $31^{\circ}(301,400)$. In addition, indications for crystalline $\mathrm{V}_{2} \mathrm{O}_{5}$ can be found in samples V-II-5.3 and V-II-4.8.

Scanning electron microscopy was used to visualize the catalysts' surface. SEM images of V-I-1.5 and V-I-8.8 are shown in Fig. 1. They were taken with a resolution of $1 \mu \mathrm{m}$ (magnification 10000) in case of the low loaded sample and $200 \mathrm{~nm}$ (magnification 20000 ) in case of the highly loaded sample.

V-I-1.5 in Fig. 1a) shows only typical features of the $\gamma-\mathrm{Al}_{2} \mathrm{O}_{3}$ support material. There is no indication of crystalline $\mathrm{V}_{2} \mathrm{O}_{5}$, whereas the surface of $\mathrm{V}-\mathrm{I}-8.8$ in Fig $1 \mathrm{~b}$ ) is slightly covered with orthorhombic $\mathrm{V}_{2} \mathrm{O}_{5}$ needles. In comparison, V-II-8.8 obtained from ball-milling shows fractured vanadia particles with a size much larger than the needles mentioned above (images not shown for sake of brevity). In case of the catalysts from ball-milling, these particles were also detected by XRD experiments. 


\subsection{Nature of $\mathrm{VO}_{x}$ species}

Since sensitivity of X-ray diffraction is limited to detect crystalline $\mathrm{V}_{2} \mathrm{O}_{5}$ and blind to dispersed $\mathrm{VO}_{\mathrm{x}}$ species, Raman and UV/Vis-DRS characterization studies were also undertaken in order to obtain more definitive information about the possible presence of crystalline $\mathrm{V}_{2} \mathrm{O}_{5}$ nanoparticles and surface $\mathrm{VO}_{\mathrm{x}}$ species. Fig. 2a) and b) show Raman spectra within the spectral range from 750 to $1150 \mathrm{~cm}^{-1}$ since characteristic bands due to the $\mathrm{V}=\mathrm{O}$ stretching vibration of crystalline $\mathrm{V}_{2} \mathrm{O}_{5}$ as well as dispersed $\mathrm{VO}_{\mathrm{x}}$ species can be detected in this interval [31].
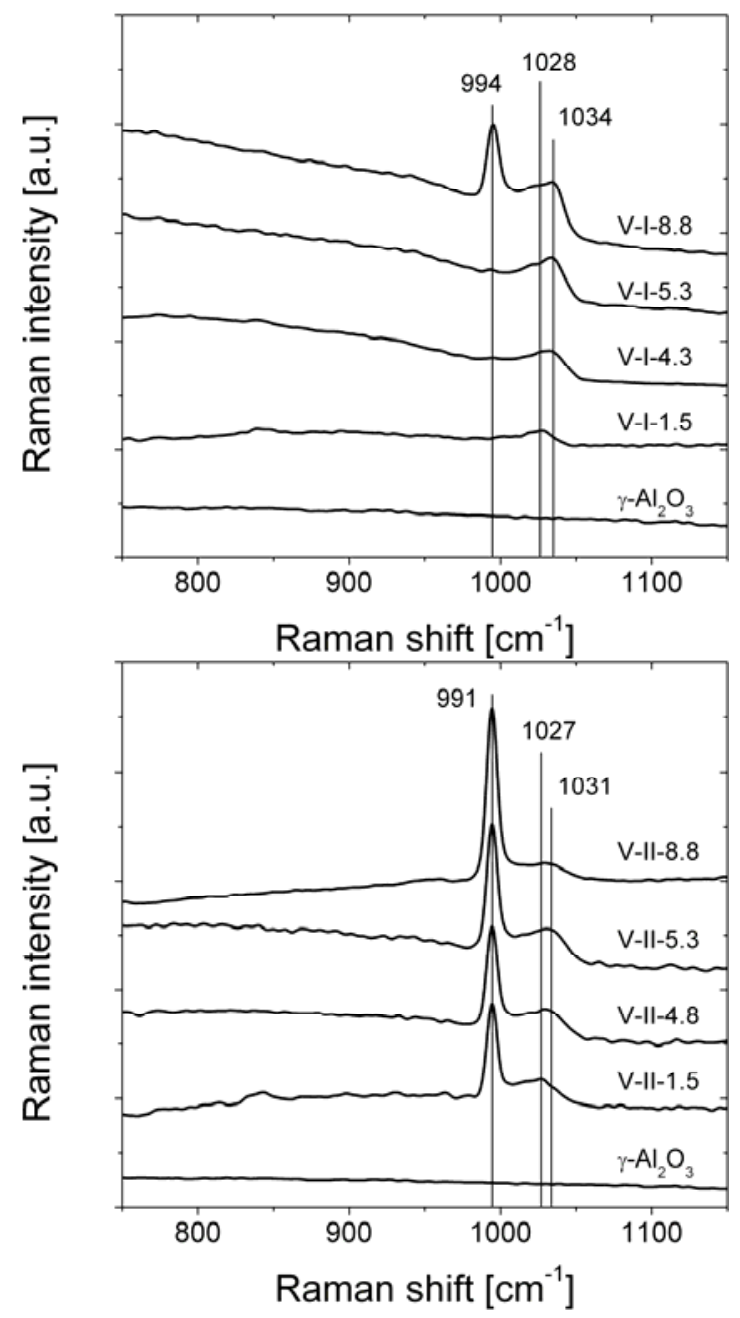

Fig. 2: Raman spectra recorded at $514 \mathrm{~nm}$ laser excitation at room temperature after dehydration of a) impregnated and b) ball-milled catalysts.

The band at about $990 \mathrm{~cm}^{-1}$ is a sensitive indicator for crystalline $\mathrm{V}_{2} \mathrm{O}_{5}$. For samples prepared by wet saturation impregnation, only V-I- 8.8 shows a band at this Raman shift, confirming SEM results and indicating that the $\mathrm{VO}_{\mathrm{x}}$ species in the other samples in this set must be well dispersed on the surface of the catalysts. However, it should be noted that the Raman cross section of $\mathrm{V}=\mathrm{O}$ bonds in crystalline $\mathrm{V}_{2} \mathrm{O}_{5}$ is about ten times higher than that in dispersed $\mathrm{VO}_{\mathrm{x}}$ [32]. Although this estimate was done on the basis of silica supported materials, it serves as a good approximation for alumina supported materials as well. Therefore, the band at $994 \mathrm{~cm}^{-1}$ in the spectrum of the sample with the highest loading points to the presence of only moderate amounts of crystalline $\mathrm{V}_{2} \mathrm{O}_{5}$ compared to the amount of dispersed $\mathrm{VO}_{\mathrm{x}}$ (band above $1000 \mathrm{~cm}^{-1}$ ). This band shifts from 1028 to $1034 \mathrm{~cm}^{-1}$ for V-I-1.5 and V-I-8.8, respectively and can be assigned to the symmetric vibration of the terminal $\mathrm{V}=\mathrm{O}$ bond $[33,34]$. The shift is due to the evolution of dispersed $\mathrm{VO}_{\mathrm{x}}$ surface species from monovanadates to polyvanadates to crystalline $\mathrm{V}_{2} \mathrm{O}_{5}$ on the alumina support. In comparison, the Raman spectra of the samples prepared by ball-milling are dominated by a distinct band at $991 \mathrm{~cm}^{-1}$ indicating the presence of crystalline $\mathrm{V}_{2} \mathrm{O}_{5}$. However, the band above $1000 \mathrm{~cm}^{-1}$ shows that a significant proportion of the originally crystalline $\mathrm{V}_{2} \mathrm{O}_{5}$ has spread on the alumina surface during the calcination step [15], forming dispersed $\mathrm{VO}_{\mathrm{x}}$ species if cross sections are taken into account. This band also undergoes a slight change from 1027 to $1031 \mathrm{~cm}^{-1}$, which can be explained as above.

Raman experiments clearly showed that in addition to crystalline $\mathrm{V}_{2} \mathrm{O}_{5}$ all samples contain dispersed $\mathrm{VO}_{\mathrm{x}}$ species, too. In order to get further insights into the type and degree of polymerization of the $\mathrm{VO}_{\mathrm{x}}$ species, UV/Vis-DRS was performed for both sets of catalytic materials. The spectra were recorded at $500{ }^{\circ} \mathrm{C}$ in a $20 / 80 \mathrm{O}_{2} / \mathrm{Ne}$ flow. For the set of catalysts prepared by wet saturation impregnation the characteristic absorbance shifts to higher wavelengths with an increase in vanadium loading (spectra not shown for sake of brevity). This shift indicates an increasing degree of polymerization and/ or co-ordination of the $\mathrm{VO}_{\mathrm{x}}$ species. The same trend can be observed for the samples prepared by ball-milling.

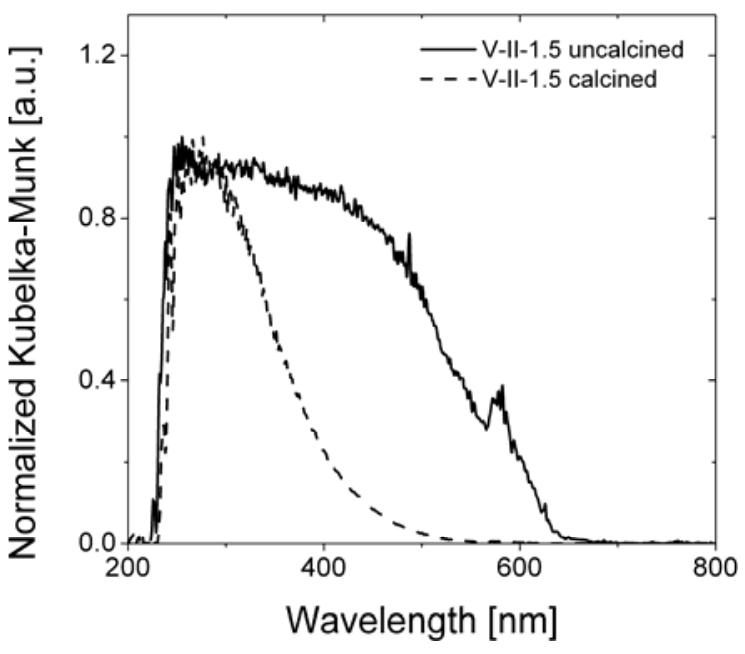

Fig.3: UV/Vis spectra of V-II-1.5 before and after calcination at $500{ }^{\circ} \mathrm{C}$ in a $20 / 80 \mathrm{O}_{2} / \mathrm{Ne}$ flow $\left(40 \mathrm{ml}_{\mathrm{n}} \mathrm{min}^{-1}\right)$. 
Results from Raman spectroscopy gave already rise to the assumption that some of the crystalline $\mathrm{V}_{2} \mathrm{O}_{5}$ that was used for preparing the second set of catalytic samples must have spread on the catalysts' surface to form amorphous $\mathrm{VO}_{\mathrm{x}}$ species. In order to verify this hypothesis, UV/Vis spectra of the low loaded sample obtained from ball-milling (V-II-1.5) was recorded before and after calcination at $500{ }^{\circ} \mathrm{C}$. As it is shown in Fig. 3, the spectrum before calcination is relatively broad which can be attributed to pure crystalline $\mathrm{V}_{2} \mathrm{O}_{5}$. Similarly shaped spectra were also recorded for the samples with a higher $\mathrm{VO}_{\mathrm{x}}$ surface density indicating only little differences between all uncalcined catalytic materials. However, after calcination the characteristic absorbance shifts to smaller wavelengths. Therefore, it can be concluded that a significant proportion of the crystalline $\mathrm{V}_{2} \mathrm{O}_{5}$ spreads on the catalysts' surface and forms dispersed $\mathrm{VO}_{\mathrm{x}}$ species.

Since UV/Vis spectra reflect the structure of valence and conduction bands in bulk solids, absorption edge energies were used in order to quantify the electronic properties
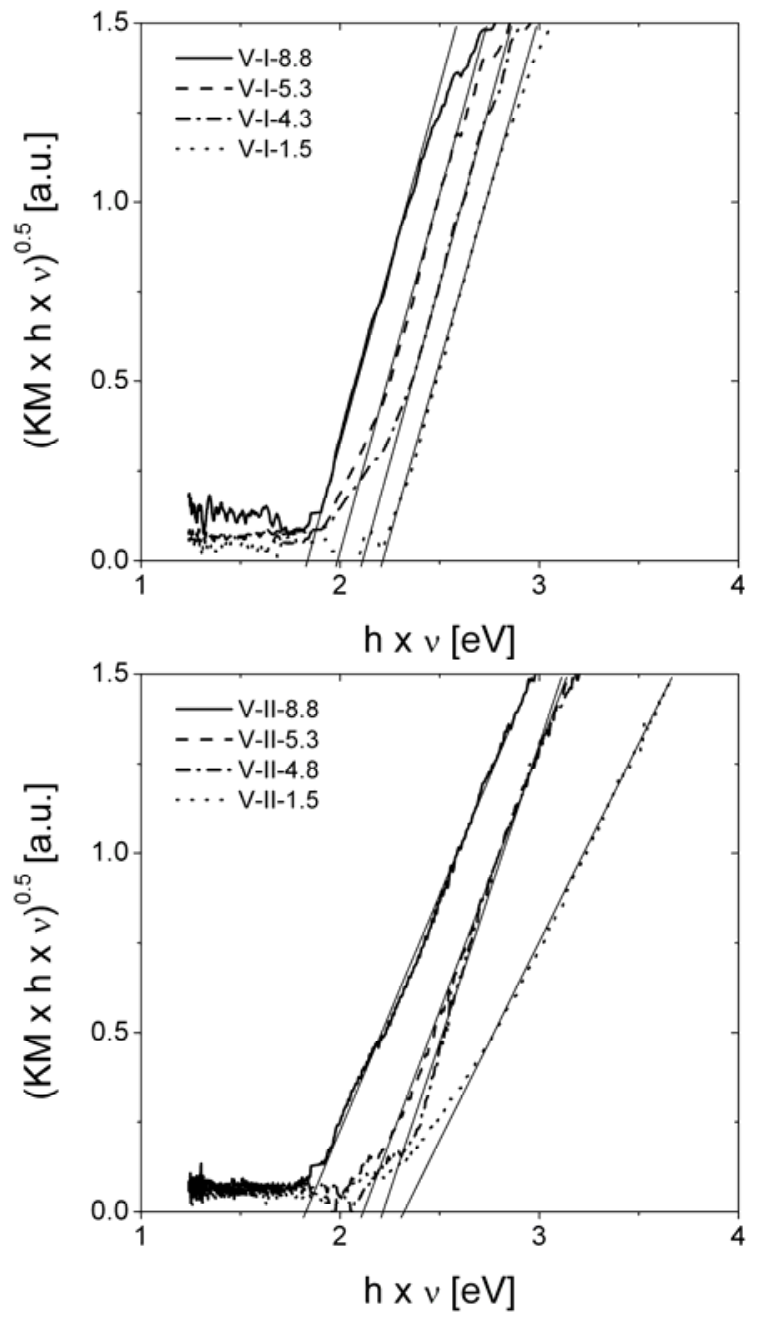

Fig. 4: Tauc's plots of a) impregnated and b) ball-milled catalysts oxidized in a $20 / 80 \mathrm{O}_{2} / \mathrm{Ne}$ flow at $500{ }^{\circ} \mathrm{C}$.

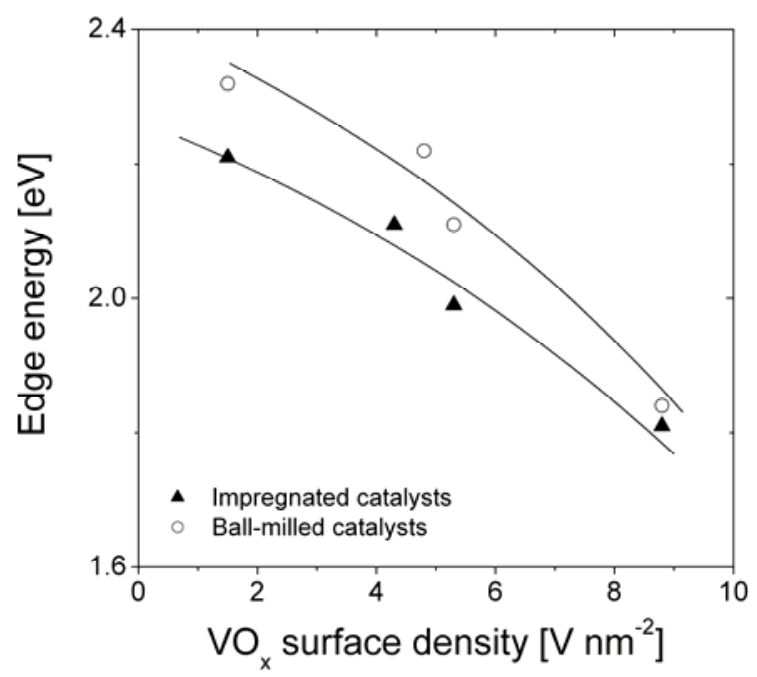

Fig. 5: Edge energies of all investigated catalytic materials as a function of $\mathrm{VO}_{\mathrm{x}}$ surface density.

of the studied materials. To this end, we applied Tauc's law [35]. The edge energy is determined from the intersect of a linear function of $\left[\mathrm{F}\left(\mathrm{R}_{\infty}\right) \cdot \mathrm{h} v\right]^{1 / 2}$ vs. hv with the $\mathrm{h} v$ axis as it is shown in Fig 4.

The estimated edge energies for both sets of catalytic materials are summarized in Fig. 5 as a function of apparent $\mathrm{VO}_{\mathrm{x}}$ surface density.

It can be seen that $\mathrm{E}_{\mathrm{g}}$ generally decreases with an increase in $\mathrm{VO}_{\mathrm{x}}$ surface density for both sets of catalytic materials. However, edge energies for the V-II series at similar $\mathrm{VO}_{\mathrm{x}}$ surface densities are higher than for the V-I series. This can be attributed to the elevated fraction of crystalline vanadia in these samples that slightly increases the resulting $E_{g}$ values. Also the decrease of edge energies for the $\mathrm{V}$ II series is somewhat more pronounced than for the V-I series. Similar results have been previously reported by Chen et al. for $\mathrm{Al}_{2} \mathrm{O}_{3}$ supported $\mathrm{VO}_{\mathrm{x}}$ species [36].

\subsection{Reducibility of $\mathrm{VO}_{x}$ species}

In order to get insights into the reducibility of the different $\mathrm{VO}_{\mathrm{x}}$ species, temperature programmed reduction experiments with hydrogen were performed over both sets of catalytic materials. Fig. 6 shows the outlet $\mathrm{H}_{2}$ concentration as a function of temperature. For comparison, the $\mathrm{H}_{2}$ concentration profile of $\mathrm{V}_{2} \mathrm{O}_{5}$ is also presented. It is characterized by two distinct peaks at temperatures of 673 and $705{ }^{\circ} \mathrm{C}$, which is in good accordance with the literature $[31,37]$. For catalysts prepared by wet saturation impregnation, the temperature of maximum reduction rate $\left(\mathrm{T}_{\max }\right)$ varies with $\mathrm{VO}_{\mathrm{x}}$ surface coverage. A single peak with a minimum at $535^{\circ} \mathrm{C}$ can be found for V-I-1.5, which first shifts to lower temperatures for V-I-4.3 $\left(518^{\circ} \mathrm{C}\right)$ and V-I$5.3\left(505^{\circ} \mathrm{C}\right)$ before it shifts back to $521^{\circ} \mathrm{C}$ for V-I-8.8. 

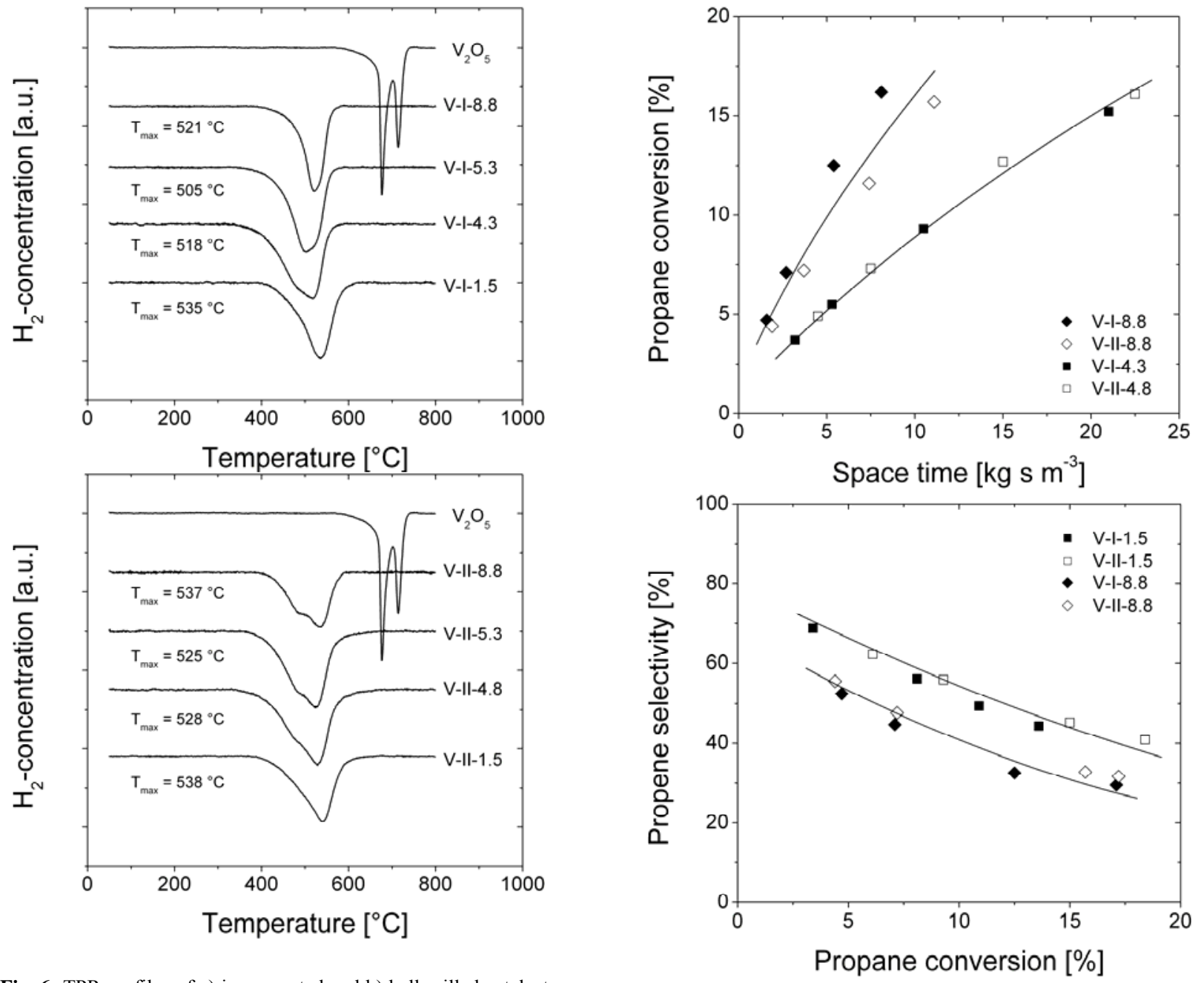

Fig. 6: TPR profiles of a) impregnated and b) ball-milled catalysts in a $5 / 95 \mathrm{H}_{2} / \mathrm{Ar}$ flow $\left(25 \mathrm{mln} \mathrm{min}^{-1}\right.$, catalyst masses 35 to $180 \mathrm{mg}$, heating rate $10{ }^{\circ} \mathrm{C} \mathrm{min}^{-1}$ ).

It is generally accepted that polymeric $\mathrm{VO}_{\mathrm{x}}$ species are reduced at somewhat lower temperatures than monomeric $\mathrm{VO}_{\mathrm{x}}$ spe cies and $\mathrm{V}_{2} \mathrm{O}_{5}$ crystallites. These findings are in good agreement with studies by Martínez-Huerta et al. who found a resembling behavior for their $\mathrm{VO}_{\mathrm{x}} / \mathrm{Al}_{2} \mathrm{O}_{3}$ samples [38]. The same trends can be found for the catalytic materials produced from ball-milling, i.e. a shift to lower and consequently back to higher $\mathrm{T}_{\max }$ values for increasing $\mathrm{VO}_{\mathrm{x}}$ surface coverage. However, the observed $\mathrm{T}_{\max }$ values are generally higher than for the impregnated samples, which can be attributed to the larger fraction of $\mathrm{V}_{2} \mathrm{O}_{5}$ crystallites that exist in the V-II series. In addition, starting from V-II5.3 a slight shoulder to the left of the main peak can be found in the profiles. This shoulder is assigned to welldispersed polymeric $\mathrm{VO}_{\mathrm{x}}$ species that co-exist with crystalline $\mathrm{V}_{2} \mathrm{O}_{5}$ in this set of samples.

The peaks related to the maximum of $\mathrm{H}_{2}$ consumption at 673 and $705{ }^{\circ} \mathrm{C}$ over pure crystalline $\mathrm{V}_{2} \mathrm{O}_{5}$ cannot be found in any of the catalytic samples that are known to contain vanadia crystallites. This phenomenon is due of the domain size of vanadia crystals which are much larger in bulk $\mathrm{V}_{2} \mathrm{O}_{5}$ than the crystallites that can be found on the

Fig. 7: Activity for a) propane conversion and b) selectivity towards propene for catalysts prepared by wet saturation impregnation $(\square, \diamond)$ and ball-milling $(\square, \diamond)$.

catalysts' surface [39]. The two high temperatures peaks at 673 and $705^{\circ} \mathrm{C}$ (and a third peak at about $860^{\circ} \mathrm{C}$ ) were assigned by Bosch et al. to a reduction sequence of bulk $\mathrm{V}_{2} \mathrm{O}_{5}$ as follows: $\mathrm{V}_{2} \mathrm{O}_{5} \rightarrow \mathrm{V}_{6} \mathrm{O}_{13} \rightarrow \mathrm{V}_{2} \mathrm{O}_{4} \rightarrow \mathrm{V}_{2} \mathrm{O}_{3}$ [40]. In comparison, smaller vanadia surface crystallites are reduced at significantly lower temperatures and do not undergo this specific sequence, which explains the absence of these peaks in all examined samples.

\subsection{Catalytic behavior}

The oxidative dehydrogenation of propane to propene was used as a model reaction in order to characterize the catalytic properties of the differently prepared $\mathrm{VO}_{\mathrm{x}} /$ $\mathrm{Al}_{2} \mathrm{O}_{3}$ materials. Both sets of catalytic materials were tested for their activity and selectivity. Fig. 7 shows a comparison between samples with a low and a high $\mathrm{VO}_{\mathrm{x}}$ surface density, respectively. 
In general, propane conversion increases with increasing space time as can be seen in Fig. 7a). This is true for all samples although the increase is slightly stronger for catalysts with a higher $\mathrm{VO}_{\mathrm{x}}$ surface density. This figure also demonstrates that the overall activity increases with an increase in $\mathrm{VO}_{\mathrm{x}}$ surface density. However, propene selectivity decreases with increasing propane conversion as shown in Fig. 7b). The decrease is due to the consecutive combustion of primarily formed propene to $\mathrm{CO}_{\mathrm{x}}$. Additionally, it can be observed that catalysts with higher $\mathrm{VO}_{\mathrm{x}}$ surface densities are not as selective as catalysts with a lower $\mathrm{VO}_{\mathrm{x}}$ surface density. This is in good accordance with the literature and previous experiments that were done by some of the present authors [30,41]. Interestingly, activity and selectivity behavior is almost identical for both catalytic materials that were obtained from very different preparation methods and vanadium precursors.

\subsection{Role of $\mathrm{VO}_{x}$ species in catalysis}

The results of our characterization analysis gave evidence that the degree of polymerization of the $\mathrm{VO}_{\mathrm{x}}$ species increases with increasing $\mathrm{VO}_{\mathrm{x}}$ surface density for both sets of catalytic materials. In the same way, catalytic activity increases with increasing $\mathrm{VO}_{\mathrm{x}}$ surface density whereas selectivity towards propene decreases at similar degrees of propane conversion. We will analyze a possible origin of the effect of $\mathrm{VO}_{\mathrm{x}}$ surface density on catalytic activity and selectivity in the ODP. Fig. 8a) shows propane consumption rates calculated corresponding to Eq. 1 versus edge energies estimated from the transformed UV/Vis spectra for both sets of $\mathrm{VO}_{\mathrm{x}} / \gamma-\mathrm{Al}_{2} \mathrm{O}_{3}$ materials, whereas Fig. 8b) shows selectivity towards propene at about $5 \% \mathrm{C}_{3} \mathrm{H}_{8}$ conversion also versus edge energies.

It can be seen that with decreasing edge energy, overall catalytic activity generally increases. Since the edge energy is related to the band gap in the electronic structure of $\mathrm{VO}_{\mathrm{x}}$ species, it is expected that the total electrical conductivity of $\mathrm{VO}_{\mathrm{x}} / \gamma-\mathrm{Al}_{2} \mathrm{O}_{3}$ materials increases with a decrease in edge energy (i.e. an increase in the apparent vanadium surface density). Kondratenko and Baerns have previously proven that $\mathrm{VO}_{\mathrm{x}} / \gamma-\mathrm{Al}_{2} \mathrm{O}_{3}$ materials are typical ntype conductors and their conductivity increases with an increase in vanadium loading [14]. The increase in the conductivity is due to an increased concentration of charge carriers, i.e. electrons. Generally, the electron concentration is determined by the energy gap between the valence (lattice oxygen) and conducting (metal cations) bands; the lower the gap the higher the electron concentration. According to [36], the activation energy for breaking the $\mathrm{C}-\mathrm{H}$ bond in $\mathrm{C}_{3} \mathrm{H}_{8}$ adsorbed over $\mathrm{VO}_{\mathrm{x}}$ species depends on the energy for electron transfer from the oxygen in this species to the metal center. Based on the discussion above, it is suggested that the increase in catalytic activity with a decrease in edge energy (as shown in Fig. 8a) is due to an improved ability of metal cations for accepting electrons.
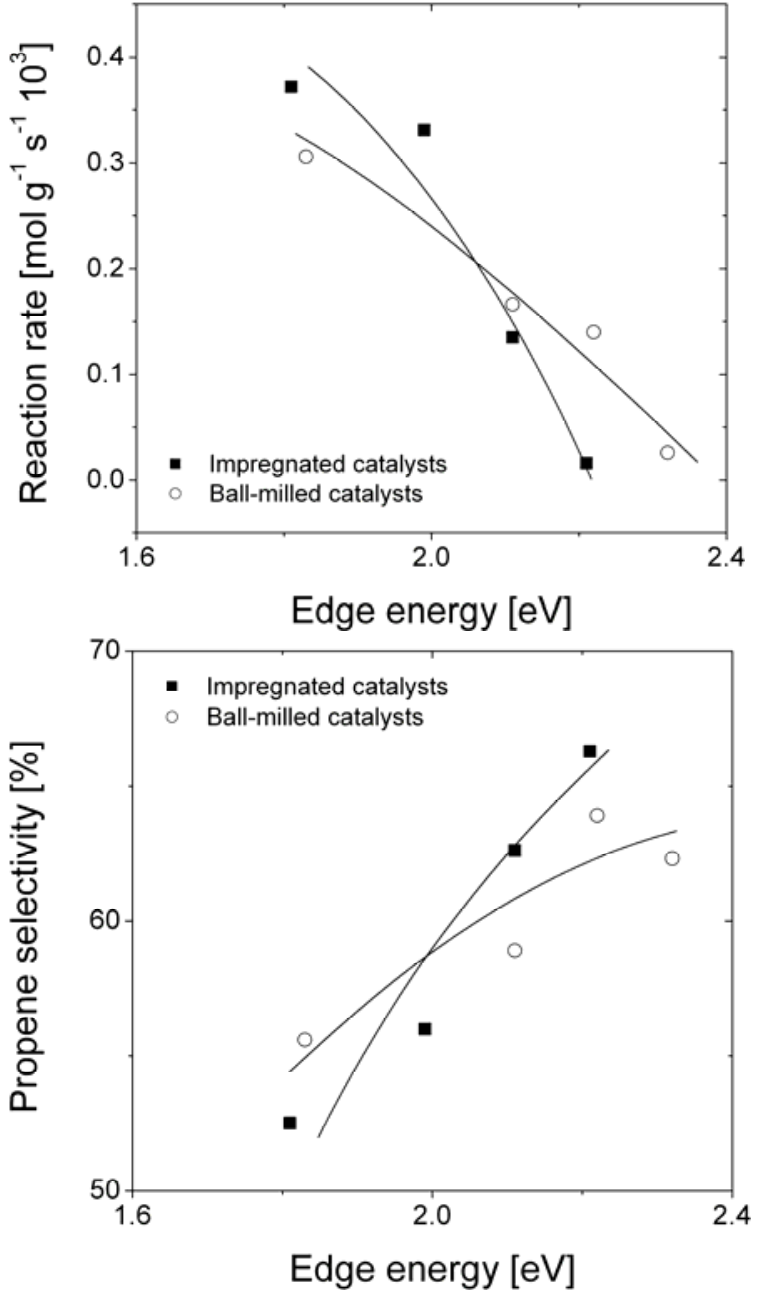

Fig. 8: Reaction rate a) and propene selectivity at $5 \%$ propane conversion b) as a function of edge energy for catalysts derived from wet saturation impregnation ( $\square$ ) and ball-milling ( $\square$ ).

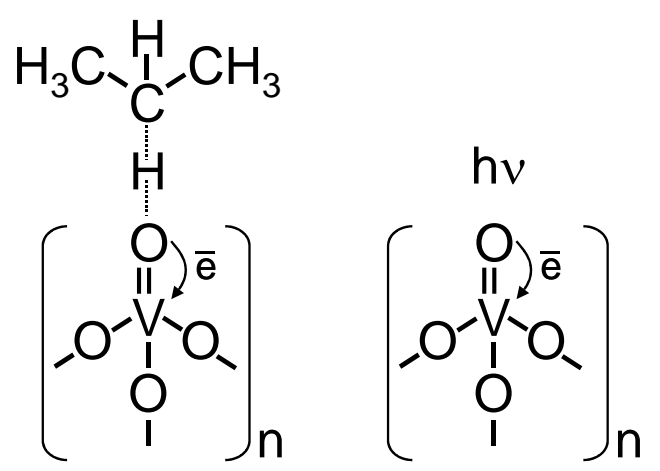

Fig. 9: Schematic illustration of electron transfer from $\mathrm{O}^{2-}$ to $\mathrm{V}^{5+}$ upon breaking the $\mathrm{C}$ - $\mathrm{H}$ bond in $\mathrm{C}_{3} \mathrm{H}_{8}$ adsorbed over $\mathrm{VO}_{\mathrm{x}}$ and under photon irradiation. 
Fig. 9 schematically illustrates the electron transfer from $\mathrm{O}^{2-}$ to $\mathrm{V}^{5+}$ upon breaking of the $\mathrm{C}-\mathrm{H}$ bond in propane over $\mathrm{VO}_{\mathrm{x}}$ species and under photon excitation of this species. It has to be stressed that this illustration is valid not only for vanadyl oxygen species but also but also for bridged oxygen between two vanadium species or between one vanadium atom and one metal species of the support.

However, it has to be noted that the dependencies for the V-I and V-II series slightly differ (i.e. the increase in activity is more pronounced for the impregnated samples than for the samples from ball-milling). For both series with increasing vanadium content the distribution of $\mathrm{VO}_{\mathrm{x}}$ surface species shifts from monovanadates to polyvanadates to crystalline $\mathrm{V}_{2} \mathrm{O}_{5}$. The same behavior was previously reported and also quantified through UV/Vis-DRS experiments by co-workers of Wachs' group $[42,43]$. However, our Raman characterization showed that all samples of the $\mathrm{V}$-II series contain crystalline $\mathrm{V}_{2} \mathrm{O}_{5}$, which is known to be less active for propane conversion and less selective towards propene. Therefore, the dependency of the reaction rate on edge energy for the samples from ball-milling is not as pronounced as for the samples from wet saturation impregnation.

Selectivity towards propene at similar degrees of propane conversion generally increases with increasing edge energies as shown in Fig. 8b). It implies that $\mathrm{VO}_{\mathrm{x}}$ species with a higher degree of polymerization tend to be less selective towards propene than $\mathrm{VO}_{\mathrm{x}}$ species with a lower degree of polymerization. As described above, total electrical conductivity of the $\mathrm{VO}_{\mathrm{x}} / \gamma-\mathrm{Al}_{2} \mathrm{O}_{3}$ materials increases with decreasing edge energies, which results in a higher activity for propane conversion. However, catalytic activity does not only increase for propane conversion as described by the rate constant $\mathrm{k}\left(\mathrm{C}_{3} \mathrm{H}_{8}\right)$ but also for propene conversion as described by the rate constant $\mathrm{k}\left(\mathrm{C}_{3} \mathrm{H}_{6}\right)$. If activity increases with increasing vanadium content (i.e. increasing degree of polymerization), selectivity towards propene depends on the ratio of $\mathrm{k}\left(\mathrm{C}_{3} \mathrm{H}_{6}\right) / \mathrm{k}\left(\mathrm{C}_{3} \mathrm{H}_{8}\right)$. The stronger the increase of $\mathrm{k}\left(\mathrm{C}_{3} \mathrm{H}_{6}\right)$ with increasing vanadium content in comparison to the increase of $\mathrm{k}\left(\mathrm{C}_{3} \mathrm{H}_{8}\right)$, the lower the selectivity towards propene. This relationship was previously shown by Argyle et al. [12].

However, it has to be noted that the dependencies for the V-I and V-II series experience a slightly different slope. The increase in selectivity with increasing $\mathrm{E}_{\mathrm{g}}$ is more pronounced for the impregnated samples than for samples from ball-milling. Since all samples from ball-milling contain crystalline vanadia, which is known to be less active and less selective, the transformation of the fraction of dispersed $\mathrm{VO}_{\mathrm{x}}$ surface species from monovanadates to polyvanadates to $\mathrm{V}_{2} \mathrm{O}_{5}$ crystallites is not as significant as in the samples from wet saturation impregnation. Therefore, the dependency in Fig. 8b) for the V-II series is less intense as for the V-I series.

\section{Conclusions}

Two sets of $\mathrm{VO}_{\mathrm{x}} / \gamma-\mathrm{Al}_{2} \mathrm{O}_{3}$ catalysts were prepared from wet saturation impregnation and ball-milling of $\gamma$ $\mathrm{Al}_{2} \mathrm{O}_{3}$ and crystalline $\mathrm{V}_{2} \mathrm{O}_{5}$ resulting in very similar physico-chemical and catalytic properties of the obtained materials. In both cases, temperature treatment during catalyst preparation leads to a distribution of monomeric and polymeric $\mathrm{VO}_{\mathrm{x}}$ species as well as $\mathrm{V}_{2} \mathrm{O}_{5}$ crystallites on the support material surface. When correlating edge energies from UV/Vis-DRS experiments with catalytic performance, very similar dependencies for both examined materials can be observed although very different preparation methods were used. It appears that the deviations in the characterization of both examined materials do not play a major role for the catalytic performance under reaction conditions. However, there is evidence that the catalytic behavior of $\mathrm{VO}_{\mathrm{x}}$ surface species changes if vanadium content is increased. It was shown that $\mathrm{VO}_{\mathrm{x}}$ species with a higher degree of polymerization appear to be more active for propane conversion but less selective towards propene. Since $\mathrm{E}_{\mathrm{g}}$ is related to the electronic structure of $\mathrm{VO}_{\mathrm{x}}$ species, it is expected that the band gap decreases and total electrical conductivity of $\mathrm{VO}_{\mathrm{x}} / \gamma-\mathrm{Al}_{2} \mathrm{O}_{3}$ materials increases with a decrease in edge energy. Therefore, the transfer of free electrons from oxygen atoms to metal centers is facilitated in materials with lower edge energies. This leads to an easier $\mathrm{C}-\mathrm{H}$ bond activation, which is the rate determining step for both, propane and propene conversion. However, with decreasing edge energies the rate for propene conversion increases stronger than the rate for propane conversion.

\section{Acknowledgements}

This work was funded by the Deutsche Forschungsgemeinschaft (DFG) as part of the Sonderforschungsbereich 546 ("Structure, dynamics and reactivity of transition metal oxide aggregates", http://www.chemie.huberlin.de/sfb546). Furthermore, the authors are grateful to F. Schmidt (TU Berlin) for SEM images, S. Khennache (TU Berlin) for preliminary experiments prior to this work and K. Menge (TU Berlin) for preparing the impregnated catalytic samples. In addition, O. Schwarz would like to thank the State of Berlin for granting a NaFöG-Scholarship funding his $\mathrm{PhD}$ thesis and $\mathrm{C}$. Hess would like to thank the DFG for providing an Emmy Noether fellowship. 


\section{References}

[1] M. Baerns, O. Buyevskaya, Catal. Today 45 (1998) 13.

[2] J.F. Brazdil, Top. Catal. 38 (2006) 289.

[3] F. Cavani, N. Ballarini, A. Cericola, Catal. Today 127 (2007) 113.

[4] E.A. Mamedov, V. Cortés Corberán, Appl. Catal. A 127 (1995) 1 .

[5] O.V. Buyevskaya, M. Baerns, Catal. Today 42 (1998) 315.

[6] T. Blasco, J.M. López Nieto, Appl. Catal. A 157 (1997) 117.

[7] D. Wolf, N. Dropka, Q. Smejkal, O. Buyevskaya, Chem. Eng. Sci. 56 (2001) 713.

[8] O.V. Buyevskaya, M. Baerns, Catal. Today 16 (2002) 155.

[9] M. Baerns, G. Grubert, E.V. Kondratenko, D. Linke, U. Rodemerk, Oil Gas-Eur. Mag. 1 (2003) 36.

[10] B.M. Weckhuysen, D.E. Keller, Cat. Today 78 (2003) 25.

[11] I.E. Wachs, B.M. Weckhuysen, Appl. Catal. A 157 (1997) 67.

[12] M.D. Argyle, K. Chen, A.T. Bell, E. Iglesia, J. Catal. 208 (2002) 139

[13] A. Khodakov, B. Olthof, A.T. Bell, E. Iglesia, J. Catal. 181 (1999) 205.

[14] E.V. Kondratenko, M. Baerns, Appl. Catal. A 222 (2001) 133.

[15] N. Steinfeld, D. Müller, H. Berndt, Appl. Catal. A 272 (2004) 201.

[16] G. Centi, Appl. Catal. A 147 (1996) 267.

[17] [17] J.B. Stelzer, H. Kosslick, J. Caro, D. Habel, E. Feike, H. Schubert, Chem. Ing. Tech. 75 (2003) 872.

[18] J.B. Stelzer, M.-M. Pohl, H. Kosslick, J. Caro, D. Habel, E. Feike, H. Schubert, Chem. Ing. Tech. 75 (2003) 1656.

[19] .B. Stelzer, A. Feldhoff, J. Caro, M. Fait, D. Habel, E. Feike, H. Schubert, Chem. Ing. Tech. 76 (2004) 1086.

[20] E.P. Reddy, R.S. Varma, J. Catal. 221 (2004) 93.

[21] J. Le Bars, A. Auroux, M. Forissier, J.C. Vedrine, J. Catal. 162 (1996) 250.

[22] J.M. López Nieto, J. Soler, P. Concepcion, J. Herguido, M. Menendez, J. Santamaria, J. Catal. 185 (1999) 324.
[23] J.L. Male, H.G. Niessen, A.T. Bell, T.D. Tilley, J. Catal. 194 (2000) 431.

[24] E.V. Kondratenko, O.V. Buyevskaya, M. Baerns, Topics Catal. 15 (2001) 175.

[25] E.V. Kondratenko, M. Cherian, M. Baerns, X. Su, R. Schlögl, X. Wang, I.E. Wachs, J. Catal. 234 (2005) 131.

[26] E.V. Kondratenko, N. Steinfeldt, M. Baerns, Phys. Chem. Chem. Phys. 8 (2006) 1624.

[27] K. Routray, K.R.S.K. Reddy, G. Deo, Appl. Catal. A 265 (2004) 103.

[28] [28] C. Pak, A.T. Bell, T.D. Tilley, J. Catal. 206 (2002) 49.

[29] O.R. Evans, A.T. Bell, T.D. Tilley, J. Catal. 226 (2004) 292.

[30] B. Frank, A. Dinse, O. Ovsitser, E.V. Kondratenko, R. Schomäcker, Appl. Catal. A 323 (2007) 66.

[31] Z. Wu, H.-S. Kim, P.C. Stair, S. Rugmini, S.D. Jackson, J. Phys. Chem. B 109 (2005) 2793.

[32] S. Xie, E. Iglesia, A.T. Bell, Langm. 16 (2000) 7162.

[33] M.A. Vuurman, I.E. Wachs, J. Phys. Chem. 96 (1992) 5008.

[34] X. Gao, M.A. Bañares, I.E. Wachs, J. Catal. 188 (1999) 325.]

[35] J. Tauc, in "Amorphous and Liquid Semiconductors" (J. Tauc, Ed.), Plenum, London, 1974.

[36] K. Chen, A.T. Bell, E. Iglesia, J. Catal. 209 (2002) 35.

[37] F. Klose, T. Wolff, H. Lorenz, A. Seidel-Morgenstern, Y. Suchorski, M. Piórkowska, H. Weiss, J. Catal. 247 (2007) 176.

[38] M.V. Martínez-Huerta, X. Gao, H. Tian, I.E. Wachs, J.L.G Fierro, M.A. Bañares, Cat. Today 118 (2006) 279.

[39] M.M. Koranne, J.G. Goodwin, Jr., G. Marcelin, J. Catal. 148 (1994) 369.

[40] H. Bosch, B.J. Kip, J.G. van Ommen, P.J. Gellings, J. Chem. Soc., Faraday Trans. 180 (1984) 2479.

[41] O. Schwarz, B. Frank, C. Hess, R. Schomäcker, Cat. Comm. 9 (2008) 229.

[42] T. Kim, I.E. Wachs, J. Catal. 255 (2008) 197.

[43] H. Tian, E.I. Ross, I.E. Wachs, J. Phys. Chem. B 110 (2006) 9593. 